\title{
The effect of breed type and lactation status on reproductive performance in Awassi ewes
}

\author{
R.T. Kridli ${ }^{\#}$, A.Y. Abdullah and M.Q. Husein \\ Department of Animal Production, Faculty of Agriculture, \\ Jordan University of Science and Technology, Irbid 22110, Jordan
}

\begin{abstract}
This study was conducted to evaluate the effect of breed types and lactation status on reproductive performance of hormonally-treated Awassi ewes. A total of 282 ewes were treated with intravaginal progestagen sponges and equine chorionic gonadotropin. Ewes were mated with fertile rams following sponge removal. Lambing rate was similar between brown- and black-faced ewes, while the percentage of multiple births, fecundity and prolificacy were greater in black-faced ewes. Lambing rate and the percentage of multiple births were similar between lactating and dry ewes. Fecundity tended to be greater in lactating ewes, while prolificacy was similar regardless of lactation status. Results of the present study indicate that black-faced Awassi ewes respond better to hormonal treatment than brown-faced ewes while the lactation status does not appear to influence the ewes' response to hormonal treatment.
\end{abstract}

Keywords: Awassi sheep, breed type, lactation, oestrus, lambing

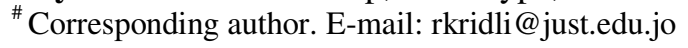

\section{Introduction}

The application of oestrus synchronisation programmes has been well-documented since the 1970s. Oestrus synchronisation can be accomplished by either extending the luteal phase (exogenous progestagen administration) or by inducing luteolysis (not possible during anoestrus). The use of vaginal progestin pessaries along with gonadotropin administration has been the method of choice for oestrus synchronisation in sheep and goats (Wildeus, 2000). This method has been used for oestrus induction (Zarkawi et al., 1999) and synchronisation (Evans et al., 2004) programmes. The responses of different breeds of sheep to oestrus synchronisation may vary [Reviewed by Wildeus (2000)].

Awassi is a fat-tailed sheep breed that is indigenous to many near eastern countries (Epstein, 1982). The majority of Awassi sheep have brown faces while some (around 10\% in traditionally raised sheep flocks in Jordan) have black faces (Breeds of Livestock, Oklahoma State University). Successful induction of oestrus can be achieved in Awassi ewes raised under arid environmental conditions (Abdullah et al., 2002). Many local sheep producers believe that black-faced Awassi outperform brown-faced Awassi (greater fertility, prolificacy and milk production). For this reason, this study was conducted to evaluate the effect of breed type (black-faced $v s$. brown-faced Awassi ewes) and lactation status on reproductive performance of Awassi ewes.

\section{Materials and Methods}

This study was conducted in the Northern Badia region of Jordan. The normal breeding season of Awassi ewes is between July and December (Epstein, 1982). Even though this study was conducted in July, none of the ewes were cycling at that time. A total of 282 ewes were utilized in the study. Two hundred and twenty four ewes were brown faced while the remaining ewes (58) were black faced. Of the total number of ewes, 173 were lactating and 109 ewes were dry. However, none of the lactating ewes were suckling their lambs. Even though black-faced ewes are thought to have better performance, many sheep producers prefer to cull them from their flocks because they are not as docile as brown-faced ewes, especially during the process of hand milking.

Ewes were raised under traditional management conditions (semi-extensive management system) being grazed during the day and supplemented with barley and wheat bran in the evening. Rams and ewes were run together before the experiment started until being separated one week before sponge insertion. All ewes had lambed at least three months before the start of the experiment. Ewes were fitted with $40 \mathrm{mg}$ 
fluorogestone acetate (FGA) sponges (Ceva Sante Animale, France). Sponges were inserted for a period of 12 days. At the time of sponge removal, each ewe received an intramuscular dose of $500 \mathrm{IU}$ eCG. Fertile rams were mated with the ewes immediately following eCG administration. Oestrus was monitored for a period of five days. Lambing data (lambing date, the number of offspring, and lamb sex) were recorded five months later.

Data were analyzed as a completely randomized design. The statistical analyses were conducted using the MIXED procedure of SAS (1997). Least square means were calculated and the effects of breed type and lactation status and their interaction on the interval to onset of oestrus, prolificacy and fecundity were evaluated. Oestrus expression, lambing rate and the number of multiple births were analyzed by Chi Square (SAS, 1997).

\section{Results}

Overall, $93.2 \%$ of the ewes expressed oestrus following the introduction of the rams. The interval from sponge removal to onset of oestrus was $44.5 \pm 2.7 \mathrm{~h}$. Most ewes expressed oestrus between 24 and $86 \mathrm{~h}$ post sponge removal. A total of $243(86.1 \%)$ ewes lambed from mating at the induced oestrus. No breed type by lactation status interactions was detected with respect to any of the variables.

Table 1 shows the effect of breed type on reproductive responses. No differences in oestrus expression, interval from sponge removal to onset of oestrus and lambing rate were observed between the two breed type groups. The percentage of multiple births $(\mathrm{P}<0.01)$, fecundity $(\mathrm{P}<0.05)$ and prolificacy $(\mathrm{P}<0.05)$ were greater in the black-faced ewes.

Table 1 The effect of breed type on reproductive parameters in Awassi ewes induced using fluorogestone acetate sponges and eCG

\begin{tabular}{ccc}
\hline Variable & \multicolumn{2}{c}{ Breed type } \\
\cline { 2 - 3 } & $\begin{array}{c}\text { Brown } \\
(\mathrm{n}=224)\end{array}$ & $\begin{array}{c}\text { Black } \\
(\mathrm{n}=58)\end{array}$ \\
\hline Oestrus expression (\%) & 92.9 & 94.8 \\
Interval to onset of oestrus (h) (mean \pm s.e. $\left.^{1}\right)$ & $45.8 \pm 2.9$ & $42.6 \pm 3.2$ \\
Number of lambed ewes & 191 & 52 \\
Lambing rate (\%) & 85.3 & 89.7 \\
No. of multiple births & $50 / 191^{\mathrm{a}}$ & $25 / 52^{\mathrm{b}}$ \\
Multiple births (\%) & $26.2^{\mathrm{a}}$ & $48.1^{\mathrm{b}}$ \\
Fecundity (mean \pm s.e.) & $0.99^{\mathrm{c}} \pm 0.1$ & $1.27^{\mathrm{d}} \pm 0.1$ \\
Prolificacy (mean \pm s.e.) & $1.32^{\mathrm{c}} \pm 0.04$ & $1.56^{\mathrm{d}} \pm 0.1$
\end{tabular}

${ }^{\mathrm{a}, \mathrm{b}}$ Means within a row with different superscripts differ $(\mathrm{P}<0.01),{ }^{\mathrm{c}, \mathrm{d}}$ Means within a row with different superscripts tend to differ $(\mathrm{P}<0.1),{ }^{1}$ s.e. $=$ standard error.

Table 2 shows the effect of lactation status on reproductive parameters. Lactation did not affect ( $\mathrm{P}>0.05$ ) oestrus expression, interval to onset of oestrus, lambing rate and the percentage of multiple births in the two types of Awassi ewes used in this experiment. Fecundity tended to be greater $(\mathrm{P}<0.10)$ in lactating ewes (1.24 \pm 0.05 and $1.03 \pm 0.1$ lambs per ewe in the lactating and dry ewes, respectively) while prolificacy was similar regardless of lactation status.

\section{Discussions}

This study evaluated the effect of ewe breed type and lactation status on the response of Awassi ewes to hormonal treatment. The success of such treatment programme is judged by the percentage of mated and lambed ewes. Hormonal treatment, in the present study, was successful in inducing oestrus following sponge removal. Oestrus expression and the interval to onset of oestrus were similar among ewes regardless of breed type or lactation status. The percentage of ewes expressing oestrus and the interval to onset of oestrus were comparable to previous studies (Abdullah et al., 2002; Zeleke et al., 2005; Emsen \& Yaprak, 2006). The 
successful induction of oestrus resulted in relatively high lambing rates $(86.1 \%)$ regardless of breed type or lactation status. These results were better than the lambing rates previously observed in Awassi ewes (Abdullah et al., 2002; Husein \& Kridli; 2002) while being comparable to other studies that utilized similar synchronisation protocols followed by natural mating (Carlson et al., 1989; Zaim et al., 1996).

Table 2 The effect of milking status on reproductive parameters in Awassi ewes induced using fluorogestone acetate sponges and eCG

\begin{tabular}{ccc}
\hline Variable & \multicolumn{2}{c}{ Lactation status } \\
\cline { 2 - 3 } & $\begin{array}{c}\text { Lactating } \\
(\mathrm{n}=173)\end{array}$ & $\begin{array}{c}\text { Non-lactating } \\
(\mathrm{n}=109)\end{array}$ \\
\hline Oestrus expression (\%) & 93.1 & 93.6 \\
Interval to onset of oestrus (h) (mean \pm s.e. $\left.^{1}\right)$ & $46.3 \pm 2.8$ & $43.5 \pm 3.1$ \\
Number of lambed ewes & 148 & 95 \\
Lambing rate (\%) & 85.5 & 87.1 \\
No. of multiple births & $48 / 148$ & $23 / 95$ \\
Multiple births (\%) & 32.4 & 24.2 \\
Fecundity (mean \pm s.e.) & $1.24^{\mathrm{a}} \pm 0.1$ & $1.03^{\mathrm{b}} \pm 0.1$ \\
Prolificacy (mean \pm s.e.) & $1.39 \pm 0.1$ & $1.30 \pm 0.1$
\end{tabular}

$\overline{{ }^{a, b} \text { Means within a row with different superscripts tend to differ }(\mathrm{P}<0.1),{ }^{1} \text { s.e. }=\text { standard error }}$

Black-faced ewes had a better response to eCG administration (as evident by the greater multiple births, fecundity and prolificacy), which may indicate a possible genetic difference between the two types of Awassi ewes namely black-faced $v s$. brown-faced types. Genetic differences between breeds have been shown to affect twinning rate in hormonally treated ewes (Emsen \& Yaprak, 2006). The percentages of multiple births were $26.2 \%$ and $48.1 \%$ in brown- and black-faced ewes, respectively. The percentage of multiple births in non-hormonally treated Awassi ewes under intensive management conditions is about $10 \%$ (Yavuzer, 2005). Even though hormonal treatment is effective in inducing oestrus in Awassi ewes (Abdullah et al., 2002), its effect on the improvement in fecundity is limited. The percentage of multiple births increases to around $25 \%$ when progestagen and eCG were used (Abdullah et al., 2002), which is also similar to the percentage obtained in brown-faced ewes in the current study. Thus, the higher twinning rate obtained in the black-faced ewes (most probably due to inherent factors) clearly indicates their superiority over brown-faced ewes in terms of reproduction performance.

No differences in lambing rates were observed in the present study between lactating and dry ewes. This is in contrast with the results of Lopez Sebastian \& Inskeep (1988) who reported lower pregnancy rates in dry than in lactating ewes. Such contradiction may be due to factors including season of treatment, ewe breed and the stage of lactation. Multiple births and prolificacy were similar while fecundity tended to be greater in lactating ewes. This could be attributed to the numeric difference in multiple births observed between lactating and dry ewes (32.4\% and $24.2 \%$, respectively). Lactation and suckling intensity can delay the onset of first postpartum ovulation (Scaramuzzi et al., 1996; Abu Ishmais et al., 2004). This delay may be related to increased prolactin concentrations, which suppresses gonadotropin secretion in suckled ewes (Mitchell et al., 1998). This may be the case when ewes are not induced to cycle during anoestrus. However, when hormonally treated, several studies reported successful induction of oestrus in lactating ewes (Alifakiotis et al., 1982; Laliotis et al., 1998; Abdullah et al., 2002) using progestagen and eCG.

\section{Conclusions}

The present results indicate that semi-extensively raised Awassi ewes can be successfully induced to enter the breeding season through the administration of progestagen sponges and eCG. Black-faced Awassi ewes responded better to hormonal treatment than brown-faced ewes (possibly due to genetically different twinning rates between these breed types), while the lactation status does not appear to influence the ewes' response to hormonal treatment. 


\section{Acknowledgements}

This project was funded by The Jordan Badia Research and Development Centre/ The Higher Council of Science and Technology. Thanks are due to A.N. Al-Yacoub for assistance in data collection.

\section{References}

Abdullah, A.Y., Husein, M.Q. \& Kridli, R.T., 2002. Protocols for estrus synchronization in Awassi ewes under arid environmental conditions. Asian-Aust. J. Anim. Sci. 15, 957-962.

Abu Ishmais, M.A., Kridli, R.T. \& Omer, S.A., 2004. Body weight change, milk production and reproductive parameters in suckled vs. non-suckled Awassi ewes. Asian-Aust. J. Anim. Sci. 17, 1236-1240.

Alifakiotis, T., Michailidis, I. \& Gavrilidis, G., 1982. Induced breeding in anestrous milking ewes of dairy breeds: Comparison of norgestomet, medroxyprogesterone and fluorogestone in two regimes of PMSG. Theriogenology 17, 603-610.

Breeds of livestock. Oklahoma State University. http://www.ansi.okstate.edu/breeds/sheep/awassi/index.htm.

Carlson, K.M., Pohl, H.A., Marcek, J.M., Muser, R.K. \& Wheaton, J.E., 1989. Evaluation of progesterone controlled internal drug release dispenser for synchronization of estrus in sheep. Anim. Reprod. Sci. $18,205-218$.

Emsen, E. \& Yaprak, M., 2006. Effect of controlled breeding on the fertility of Awassi and Red Karaman ewes and the performance of the offspring. Small Rumin. Res. 66, 230-235.

Epstein, H., 1982. Awassi sheep. Wrld Anim. Rev. 44, 9-18.

Evans, A.C.O., Duffy, P., Crosby, T.F., Hawken, P.A.R., Boland, M.P. \& Beard, A.P., 2004. Effect of ram exposure at the end of progestagen treatment on estrus synchronization and fertility during the breeding season in ewes. Anim. Reprod. Sci. 84, 349-358.

Husein, M.Q. \& Kridli, R.T., 2002. Reproductive responses of Awassi ewes treated with either naturallyoccurring progesterone or natural progestagen. Asian-Aust. J. Anim. Sci. 15, 1257-1262.

Laliotis V., Vosniakou A., Zafrakas A., Lymberopoulos A. \& Alifakiotis T., 1998. The effect of melatonin on lambing and litter size in milking ewes after advancing the breeding season with progestagen and PMSG followed by artificial insemination. Small Rumin. Res. 31, 79-81.

Lopez Sebastian, A. \& Inskeep, E.K., 1988. Effect of lactation status, progestogen and ram exposure on response to cloprostenol in ewes during the anoestrus season. Theriogenology 30, 279-289.

Mitchell, L.M., King, M.E., Gebbie, F.E., Ranilla, M.J. \& Robinson, J.J., 1998. Resumption of oestrus and ovarian cyclicity during the postpartum period in autumn-lambing ewes is not influenced by age or dietary protein content. Anim. Sci. 67, 65-72.

SAS, 1997. SAS/STAT User's Guide, Version 6, SAS Institute Inc. Carry, N.C., USA.

Scaramuzzi, R.J., Cognie, Y. \& Downing, J.A., 1996. The ovarian secretion of androstenedione and estradiol during late pregnancy and the early postpartum period in sheep with an autotransplanted ovary. Reprod. Nutr. Dev. 36, 531-543.

Wildeus, S., 2000. Current concepts in synchronization of estrus: sheep and goats. J. Anim. Sci. 77, 1-14.

Yavuzer, U., 2005. The possibilities of twice-yearly lambing of Awassi sheep ewes without using hormones in an organic animal production system. Turk. J. Vet. Anim. Sci. 29, 27-30.

Zaim, I., Tainturier, D., Chemli, J. \& Soltani, M., 1996. Vaginal sponges and different PMSG doses to improve breeding performances of Black Thibar ewes. Rev. Med. Vet. 147, 305-310.

Zarkawi, M., Al-Merestani, M.R. \& Wardeh, M.F., 1999. Induction of synchronized estrous and early pregnancy diagnosis in Syrian Awassi ewes, outside the breeding season. Small Rumin. Res. 33, 99-102.

Zeleke, M., Greyling, J.P.C., Schwalbach, L.M.J., Muller, T. \& Erasmus, J.A., 2005. Effect of progestagen and PMSG on estrous synchronization and fertility in Dorper ewes during the transition period. Small Rumin. Res. 56, 47-53. 